\title{
Kearifan Lokal dalam Hikayat Komering Pitu Phuyang
}

\author{
Local Wisdom in the Hikayat Komering Pitu Phuyang
}

\author{
Dedi Febriyanto $^{1, *}$, Kiki Nurjana ${ }^{2}$, Eka Anista $^{3}$, dan Dedi Mardiansyah ${ }^{4}$ \\ ${ }^{1,2,3}$ Pascasarjana Universitas Lampung \\ ${ }^{4}$ STKIP Nurul Huda Sukaraja \\ ${ }^{1}$ Corresponding Email: dedifebri97@gmail.com \\ ${ }^{2}$ Email: kikinurjana053@gmail.com \\ ${ }^{3}$ Email: anistayuhu16@gmail.com \\ ${ }^{4}$ Email: bangded@stkipnurulhuda.ac.id
}

Received: 11 May 2021 Accepted: 26 May 2021 Published: 2 August 2021

\begin{abstract}
The purpose of this study is to explore and describe local wisdom in the Hikayat Komering Pitu Phuyang. The study used a qualitative descriptive method with a sociological literature approach. Source of research data is Hikayat Komering Pitu Phuyang by Himawan Bastari. The data were collected using the reading-note technique, while the content analysis technique carried out the data analysis. The results showed that the Hikayat Komering Pitu Phuyang contains very diverse local wisdom. Local wisdom includes (1) Wangsa Buay Tumi's belief in tambo as a means of information that is believed to be true, (2) the belief system in Belaksa Kepampang and Ikahua as the embodiment of gods, (3) the tradition of giving adok as a form of appreciation, (4) ) the government system in the form of a kingdom, (5) the tradition of slaughtering virgins and virgins as evidence of worship of gods, (6) the caste tradition in royal family marriages as a symbol of honour, (7) the tradition of asceticism at the top of a mountain as a means of approaching oneself to the God, (8) society that has the principles of religious life, full responsibility, and hard work, (9) a residential system that reflects the breadth of the way the people think.
\end{abstract}

Keywords: local wisdom, saga, Komering, pitu phuyang

\begin{abstract}
Abstrak: Tujuan penelitian ini adalah untuk menggali dan mendeskripsikan kearifan lokal dalam hikayat Komering Pitu Phuyang. Penelitian menggunakan metode deskriptif kualitatif dengan pendekatan sosiologi sastra. Sumber data penelitian adalah Hikayat Komering Pitu Phuyang karya Himawan Bastari. Pengumpulan data dilakukan dengan teknik baca-catat, sedangkan analisis data dilakukan teknik analisis isi. Hasil penelitian menunjukkan bahwa hikayat Komering Pitu Phuyang mengandung kearifan lokal yang sangat beragam. Kearifan lokal yang dimaksud meliputi: (1) keyakinan Wangsa Buay Tumi terhadap tambo sebagai salah satu sarana informasi yang diyakini kebenarannya; (2) sistem kepercayaan terhadap Belaksa Kepampang dan Ikahua sebagai perwujudan dewata; (3) tradisi pemberian adok sebagai wujud penghargaan; (4) sistem pemerintahan berwujud kerajaan; (5) tradisi penyembelihan perawan dan perjaka sebagai bukti pemujaan terhadap dewata; (6) tradisi kasta dalam pernikahan keluarga kerajaan sebagai simbol kehormatan; (7) tradisi bertapa di puncak gunung sebagai sarana pendekatan diri kepada Yang Kuasa; (8) masyarakat yang memiliki prinsip hidup religius, penuh tanggung jawab, dan pekerja keras; dan (9) sistem bertempat tinggal yang mencerminkan keluasan cara pikir masyarakatnya.
\end{abstract}

Kata Kunci: kearifan lokal, hikayat, Komering, pitu phuyang

\section{To cite this article:}

Febriyanto, D., Nurjana, K., Anista, E., \& Mardiansyah, D. (2021). Kearifan Lokal dalam Hikayat Komering Pitu Phuyang. Diglosia: Jurnal Kajian Bahasa, Sastra, dan Pengajarannya, 4(3), 321-334. https://doi.org/10.30872/diglosia.v4i3.227 


\section{A. PENDAHULUAN}

Hikayat merupakan karya sastra berbentuk prosa yang berisi cerita-cerita kuno (Akmaliyah, 2013). Hikayat merupakan karya sastra lama Melayu berbentuk prosa yang berisi cerita, undang-undang, hingga silsilah yang bersifat fiksi, baik keagamaan, historis, geografis, atau gabungan dari sifat-sifat itu, dibaca untuk pelipur lara, pembangkit semangat juang tau sekedar untuk meramaikan pesta (Supratman, 1996; Alwi, 2005).

Hikayat sebagai sebuah karya sastra mengandung beragam kearifan lokal. Hal ini dikarenakan hikayat merupakan produk masyarakat. Kehadirannya sudah pasti membawa kearifan lokal, cerminan budaya luhur suatu masyarakat. Kearifan lokal merupakan salah satu wujud jati diri bangsa yang harus senantiasa digali dan dilestarikan keberadaannya. Penggalian dan pelestarian tersebut dilakukan sematamata untuk mengokohkan jati diri bangsa. Kearifan lokal merupakan gagasangagasan setempat (local) yang bersifat bijaksana, penuh kearifan, bernilai baik, yang tertanam dan diikuti oleh anggota masyarakatnya (Sartini, 2004). Kearifan lokal berkaitan dengan pemikiran, segala aktivitas dan perilaku, juga norma tatakrama yang melingkupi dan menjadi ciri khas masyarakat suatu tempat (Kasmi, 2019). Lebih tegas lagi dikatakan bahwa kearifan lokal merupakan sistem pengetahuan masyarakat lokal atau pribumi (indigenous knowledge systems) yang bersifat empirik dan pragmatis (Fachrudin, 2009:4). Bersifat empirik karena hasil olahan masyarakat secara lokal bermula dari fakta-fakta yang terjadi di sekeliling kehidupan mereka. Bersifat pragmatis karena seluruh konsep yang terbangun sebagai hasil olah pikir dalam sistem pengetahuan itu menjadi solusi dari setiap persoalan yang terjadi.

Kearifan lokal dalam suatu masyarakat tidak hanya terdiri dari norma dan nilai budaya, melainkan juga segala unsur gagasan, termasuk yang berimplikasi pada teknologi, penanganan kesehatan dan estetika (Purna, 2016) Kearifan lokal dengan demikian merupakan suatu bentuk kaidah di tengah masyarakat yang memiliki cakupan luas melingkupi seluruh aspek kehidupan. Pada dasarnya, kearifan lokal adalah segala jenis kebudayaan yang dipandang memiliki nilai luhur dan dapat dijadikan sebagai pegangan hidup bagi masyarakatnya.

Berdasarkan pendapat-pendapat di atas, dapat disimpulkan bahwa secara umum kearifan lokal dapat dikatakan sebagai segala pemikiran, gagasan, dan aktifitas suatu masyarakat yang mengandung nilai-nilai luhur di dalamnya. Kearifan lokal merupakan budaya lokal yang hidup berazazkan nilai. Sistem nilai sendiri merupakan bagian terpadu dalam etika moral yang dijabarkan dalam norma-norma sosial, sistem hukum dan adat yang berfungsi sebagai tata kelakuan untuk mengatur waktu (Koentjaraningrat, 1987).

Salah satu hikayat yang kaya akan kearifan lokalnya adalah Hikayat Komering Pitu Phuyang yang ditulis oleh Himawan Bastari. Pitu Phuyang berarti tujuh nenek moyang. Hikayat tersebut menceritakan tentang tujuh perwira kerajaan Skala Brakh yang melakukan perjalanan untuk mencari tanah harapan yang dijanjikan dewata sebagai tempat tinggal baru untuk wangsanya, Buay Tumi. Mereka harus melakukan perjalanan tersebut karena kerajaan tempat mereka tinggal dan berlindung telah direbut dan dikuasai oleh Wangsa Buay Umpu dari utara. Masyarakat Komering percaya bahwa ketujuh perwira yang memimpin Wangsa Buay Tumi tersebut adalah nenek moyang dari suku Komering. 
Hikayat Komering Pitu Phuyang sendiri merupakan sebuah cerita rakyat yang hidup di tengah masyarakat Komering. Himawan Bastari sebagai salah satu penulis yang peduli dengan kebudayaan Komering memiliki inisiatif untuk mendokumentasikan hikayat Pitu Phuyang tersebut ke dalam sebuah tulisan. Harapannya tak lain agar generasi selanjutnya dapat mengetahui muasal suku Komering sebagai salah satu suku yang adiluhung sekaligus dapat menerapkan nilai-nilai luhur yang melekat dalam sikap hidup para phuyang. Sebagaimana telah diketahui bersama bahwa hikayat merupakan salah satu karya sastra yang proses penyebarannya dilakukan dari lisan ke lisan. Begitu pula buku ini ditulis berdasarkan penuturan dan cerita-cerita para tetua suku Komering. Para tetua tersebut meyakini bahwa kelahiran suku Komering bermula dari ketujuh phuyang yang diutus oleh Dapunta Beliau Ratu Sekerumong untuk ber-muhibah mencari tanah harapan.

Pengkajian kearifan lokal dalam Hikayat Komering Pitu Phuyang dilakukan untuk mengetahui secara mendalam mengenai kearifan lokal yang dimiliki masyarakat Komering, utamanya menilik kearifan lokal tersebut melalui peradaban masa lalu. Selain itu, dengan dilakukannya pengkajian ini, akan dapat diketahui kearifan lokal apa saja yang masih lestari maupun yang telah hilang dari peradaban masyarakat Komering di masa sekarang.

Penelitian tentang kearifan lokal telah banyak dilakukan oleh beberapa peneliti. Penelitian tersebut antara lain dilakukan oleh Rafiek (2012) yang mengangkat judul penelitian, "Kearifan Lokal dalam Hikayat Raja Banjar". Hasil penelitian tersebut menunjukkan bahwa Hikayat Raja Banjar kaya dengan kearifan lokal. Adapun wujud kearifan lokal yang terkandung meliputi tradisi dan adatistiadat dalam kerajaan Banjar, norma agama, norma masyarakat, dan kelestarian alam. Penelitian relevan selanjutnya dilakukan oleh Yetti (2019) dengan judul penelitian, "Kearifan Lokal dalam Cerita Rakyat Nusantara: Upaya Melestarikan Budaya Bangsa". Hasil penelitian menunjukkan bahwa cerita rakyat yang menjadi kajian banyak mengandung nilai moral dan multikulturalisme dengan menempatkan kepentingan bangsa di atas segala perbedaan. Penelitian relevan terakhir yang diungkapkan dalam penelitian ini adalah penelitian yang dilakukan oleh Murmahyati (2011) dengan judul, "Kearifan Lokal dalam Puisi Toraja". Hasil penelitian menunjukkan bahwa kearifan lokal yang terkandung di dalam puisi Toraja meliputi nilai gotong royong, kereligiusan, kemanusiaan, kepemimpinan, dan pendidikan moral. Penelitian relevan terakhir yang diungkapkan dalam penelitian ini adalah penelitian yang dilakukan oleh Salbiah \& Fitriani (2021) dengan judul, "Analisis Penokohan Dalam Hikayat Komering Phitu Phuyang: Negeri Para Phuyang Karya Himawan Bastari". Hasil penelitian menunjukkan bahwa tokoh-tokoh yang digambarkan dalam hikayat memiliki karakter yang luhur. Khususnya ketujuh paksi yang dianggap sebagai nenek moyang suku Komering.

Tiga penelitian terdahulu yang mula-mula diungkapkan di atas memiliki kesamaan dengan penelitian ini ditinjau dari segi fokus kajian, yaitu kearifan lokal. Adapun letak perbedaannya dapat dilihat dari segi sumber data penelitian, meskipun sama-sama mengkaji karya sastra lama, namun menggunakan sumber kajian yang berbeda. Selanjutnya pada penelitian terdahulu yang terakhir diungkapkan memiliki kesamaan dari segi sumber data penelitian, yakni samasama mengkaji Hikayat Komering Pitu Phuyang yang ditulis oleh Himawan Bestari. 
Letak perbedaannya adalah dari segi fokus kajian. Penelitian terdahulu berfokus pada penokohan yang terdapat di dalam hikayat, sedangkan penelitian ini memfokuskan kajian pada kearifan lokal yang terkandung dalam Hikayat Komering Pitu Phuyang.

Bertolak dari pemaparan di atas, penelitian ini bertujuan menggali dan mendeskripsikan bentuk-bentuk kearifan lokal yang terkandung di dalam Hikayat Komering Pitu Phuyang karya Himawan Bastari. Adapun wujud kearifan lokal yang menjadi fokus penelitian ini meliputi sistem tradisi dan kebudayaan, sistem pemerintahan, sistem bertempat tinggal, sistem kepercayaan, hingga sikap hidup masyarakatnya. Hasil kajian ini diharapkan dapat memberikan sumbangsih dalam bentuk penyebarluasan kearifan lokal suku Komering yang adiluhung.

\section{B. METODE}

Penelitian ini menggunakan metode deskriptif kualitatif dengan pendekatan sosiologi sastra. Data penelitian berupa kutipan-kutipan kalimat yang mengandung kaerifan lokal. Adapun sumber data penelitian adalah Hikayat Komering Pitu Phuyang berbahasa Indonesia yang ditulis oleh Himawan Bastari. Penulisan Hikayat Komering Pitu Phuyang didasarkan pada penuturan para tetua suku Komering yang meyakini bahwa suku Komering berasal dari ketujuh paksi yang diutus oleh Dapunta Beliau Ratu Sekerumong untuk ber-muhibah mencari tanah harapan di sepanjang aliran sungai Komering. Buku ini diterbitkan pertama kali pada tahun 2019 oleh penerbit Intishar Publishing. Pengumpulan data dilakukan dengan teknik baca-catat. Mula-mula peneliti membaca dan memahami hikayat secara teliti. Selanjutnya peneliti melakukan pencatatan terhadap data-data yang mengandung kearifan lokal. Teknik analisis data dilakukan dengan menggunakan teknik analisis isi. Teknik ini digunakan karena kajian ini menekankan penggalian terhadap makna-makna di dalam teks Hikayat Komering Pitu Phuyang yang menggambarkan kearifan lokal dalam suatu kelompok masyarakat. Adapun tahapan analisis data meliputi; (1) tahap identifikasi data, (2) mereduksi data, (3) menyajikan data, (4) menginterpretasikan data, dan (5) menyimpulkan hasil interpretasi.

\section{PEMBAHASAN}

\section{Gambaran Hikayat Komering Pitu Phuyang}

Hikayat Komering Pitu Phuyang menceritakan tentang perjalanan tujuh phuyang (nenek moyang) jolma Komering dalam mencari daerah baru sebagai tempat menetap. Perjalanan ini terpaksa ditempuh setelah kerajaan tempat mereka berlindung, Skala Brakh, diserang oleh Wangsa Buay Umpu dari kerajaan Paguruyung yang beragama Islam. Perjalanan mencari tanah harapan dilakukan agar Wangsa Buay Tumi tetap terjaga keberadaannya.

Sekilas gambaran tentang ketujuh phuyang yang melakukan muhibah (perjalanan) mencari tanah harapan demi keberlangsungan hidup Wangsa Buay Tumi. Pertama, Phuyang Ratu Sabibul. Beliau merupakan panglima pasukan kaveleri gajah kerajaan Skala Brakh. Phuyang Ratu Sabibul menjadi panglima andalan dalam memper-tahankan kedaulatan Skala Brakh dari perusuh-perusuh kerajaan tetangga, Umpu Kenyanyang. Selama beberapa waktu sebelum muhibah ke muara, Ratu Sabibul baru menyelesaikan misi pemindahan ibu Negara Skala Brakh dari Kenali ke Bunuk Tenuar. Ratu Sabibul dengan atribut kepanglimaannya 
mengakhiri perjalanan para paksi ke muara (Gunung Batu), kemudian mendirikan Kepuhyangan Semendaway.

Kedua, Phuyang Minak Ratu Damang Bing. Beliau merupakan seorang prajurit laut kerajaan Skala Brakh, terbiasa menahkodai Jung sebagai kendaraan laut yang membentengi Skala Brakh dari ancaman para penyamun samudra kala itu. Berkat kelihaian Minak Ratu Damang Bing, muhibah dapat berlangsung dengan selamat sampai ke muara. Kephuyangan ini menempati suatu daratan yang kemudian dinamakan Minanga.

Ketiga, Phuyang Umpu Sipadang. Beliau merupakan perwira andalan prajurit Taruda, pasukan lapisan dua yang menjaga perbatasan negeri pegunungan Skala Brakh. Ber-perawakan sedang dengan matanya yang tajam bagaikan elang, menjadikan Umpu Sipadang diserahi tugas untuk menahkodai rakit para paksi ketika malam hari. Paksi Umpu Sipadang menjadikan sebuah padang luas untuk ditinggali. Padang tersebut akhirnya dijadikan sebagai kepuhyangan dan tempat pertama yang mereka tinggali dinamakan Gunung Terang.

Keempat, Phuyang Minak Adipati. Beliau dikenal dengan ciri khasnya yang selalu membawa peliung. Peliung merupakan senjata sakti yang beliau dapatkan dari Ratu Sekerumong. Dari atribut yang dibawanya ini, kephuyangan yang mereka dirikan dinamakan kephuyangan Pemuka Peliung. Paksi Minak Adipati merupakan sepupu dari Inang Dalom Intan Galuh, ibunda Pun Dalom Ratu Sekerumong. Kecakapan Phuyang Minak Adipati tidak perlu disanggah lagi. Selama perjalanan para paksi ke muara, beliau sangat diandalkan. Berkat kedigdayaannya, para paksi yang lain banyak terbantu olehnya.

Kelima, Phuyang Ratu Penghulu. Beliau merupakan paksi termuda dari ketujuh paksi yang ada. Beliau memiliki perawakan sedang dengan kulit yang gelap, dan beralis tebal, menambah ketampanan wajahnya. Paksi Ratu Penghulu meskipun sebagai paksi termuda, namun dalam urusan perang, beliau telah menjelajah hingga ke beberapa wilayah, bahkan sampai ke Delta Upang dalam misi penaklukan Kerajaan Criwijaya oleh Dapunta Hyang.

Keenam, Phuyang Jati Keramat. Beliau merupakan prajurit berani yang menjadi salah satu punggawa andalan lamban gedung istana Skala Brakh. Prajurit Tabuah Handak pilihan ini memiliki postur tubuh yang tinggi dengan lengan dan bahu kekar dengan segala daya yang dipunya, mengawal dan menghantarkan para paksi ke muara. Dari ketujuh paksi yang ada, hanya Jati Keramat yang mendapatkan jodoh dalam muhibah ke muara. Menurut kepercayaan masyarakat setempat, istri Phuyang Jati Keramat berasal dari bunga mayang atau pinang. Kepercayaan ini sangat membekas di tengah masyarakat hingga namanya diabadikan pada nama kephuyangan mereka, yaitu Bunga Mayang.

Ketujuh, Phuyang Sibalakuang. Beliau merupakan prajurit kesayangan Dapunta Dalom Ratu Sekerumong. Selama pengabdiannya, Sibalakuang dipercaya menjaga tunggangan sang ratu yang berupa seekor harimau. Begugawong adalah nama harimau yang biasa ditunggangi oleh sang ratu. Sedari kecil, Phuyang Sibalakuang inilah yang menjaga hewan peliharaan Ratu Sekerumong. Phuyang Sibalakuang mendirikan kephuyangan Daya dan menempatkannya di daerah Mahanggin. 


\section{Kearifan Lokal dalam Hikayat Komering Pitu Phuyang}

Hikayat Komering Pitu Phuyang memiliki kandungan kearifan lokal yang sangat beragam. Berdasarkan analisis yang dilakukan, kearifan lokal yang termuat di dalam hikayat Komering Pitu Phuyang meliputi keyakinan terhadap tambo, sistem kepercayaan yang dianut, ritual dan tradisi, sikap dan prinsip hidup, sistem tempat tinggal, dan lain sebagainya. Kearifan lokal yang terkandung di dalam hikayat Komering Pitu Phuyang secara tidak langsung juga menggambarkan sikap hidup masyarakat Komering sebagai salah satu suku sekaligus kebudayaan adiluhung yang ada di Indonesia.

\section{a. Tradisi Pemberian Adok}

Pemberian adok atau gelar merupakan salah satu tradisi luhur yang dimiliki Wangsa Buay Tumi. Adok merupakan istilah baru yang dipakai suku Komering saat ini. Sebelumnya, Juluk merupakan istilah yang digunakan suku Komering di masa lalu (Misyuraidah, 2017).

Ratu Sabibul mendapatkan adok kehormatan dari Pandita Negri Skala Brakh, Liman Meraksa. Adok yang diberikan merupakan perwujudan dari kesetiaan Sabibul terhadap Skala Brakh dan Buay Tumi (Bastari, 2019, hal. 11).

Data di atas menjelaskan Ratu Sabibul yang diberikan gelar kehormatan oleh Liman Meraksa, Pandita Negeri Skala Brakh. Pemberian adok merupakan wujud penghargaan kerajaan Skala Brakh atas jasa dan kesetiaan yang diberikan oleh Phuyang Ratu Sabibul. Pemberiaan adok menyiratkan sikap hidup Wangsa Buay Tumi yang menjunjung nilai-nilai kebaikan, terutamanya kesetiaan. Seseorang yang dengan teguh memegang nilai-nilai kebaikan layak diberikan apresiasi dan penghargaan setinggi-tingginya.

\section{b. Sistem Pemerintahan}

Pemerintahan yang dianut Wangsa Buay Tumi berdasarkan Hikayat Komering Pitu Phuyang berbentuk kerajaan, kerajaan Skala Brakh namanya. Puncak pimpinan dipegang oleh seorang raja. Raja di dalam kerajaan Skala Brakh memiliki kekuasaan mutlak.

Pusat daerah baru yang dimaksudkan oleh Ratu Sekerumong adalah daerah yang seperti dibisikkan oleh para dewata ketika Ratu sedang bersemedi di atas puncak Gunung Pesagi (Bastari, 2019, hal. 47).

Melalui data di atas, diketahui bahwa keputusan Ratu Sekerumong selaku pimpinan kerajaan Skala Brakh bersifat mutlak. Beliau memutuskan tanpa meminta pertimbangan yang lain. meskipun demikian, melalui data di atas dapat diketahui pula bahwa seorang yang didaulat menjadi raja di kerajaan Skala Brakh adalah seseorang yang memiliki tingkat spiritual tinggi. Dengan ketinggian tingkat spiritualnya tersebut, seorang raja atau ratu di kerajaan Skala Brakh selalu mendapatkan bimbingan dewata dalam memutuskan atau menghadapi segala persoalan di kerajaannya. 


\section{c. Keyakinan Terhadap Tambo}

Wangsa Buay Tumi merupakan wangsa yang berperadaban. Raja pertama kerajaan Skala Brakh, La Laula, telah menghimpun peristiwa-peristiwa penting, baik di masa lalu maupun di masa mendatang dalam sebuah buku yang disebut tambo. Tambo adalah kitab yang berisi peristiwa-peristiwa penting dan diyakini kebenarannya oleh seluruh Wangsa Buay Tumi.

Salah satu isi tambo yang sering diceritakan Kajong Dalom kepada Ratu Sekerumong adalah ramalan tentang ratu terakhir yang memimpin kerajaan Skala Brakh.

"Engkau ratu terakhir dan terbesar wangsa ini. Wangsa baru yang berasal dari utara akan merobohkan Belaksa Kepampang dan menghancurkan altar batu Ikahua sesembahan kita. Mereka mendirikan kuasa dewa baru sebagai pengganti dewa kita" (Bastari, 2019, hal. 23).

Data di atas merupakan tuturan Dapunta Sangkan kepada Ratu Sekerumong. Dapunta Sangkan menyitir isi tambo yang menjelaskan ramalan tentang kehancuran dari kerajaan Skala Brakh. Berdasarkan ramalan yang ditulis oleh Kajong Tujuk La Laula, Ratu Sekerumong adalah ratu terbesar yang pernah memimpin kerajaan Skala Brakh. Namun, beliau juga adalah ratu terakhir, yang artinya kehancuran kerajaan Skala Brakh ada pada masa kepemimpinannya. Melalui isi tambo, dapat diketahui bahwa kerajaan Skala Brakh akan dihancurkan oleh wangsa baru yang berasal dari utara. Mereka akan menghancurkan Belaksa Kepampang dan Ikahua serta menggantikannya dengan sesembahan yang baru.

\section{d. Tradisi Penyembelihan Perawan dan Perjaka}

Tradisi penyembelihan perawan dan perjaka digelar sebagai persembahan untuk Belaksa Kepampang dan Ikahua yang mereka puja. Pengorbanan tersebut merupakan simbol pemujaan sekaligus keyakinan yang kuat Wangsa Buay Tumi terhadap dua sesembahan tersebut.

Belaksa Kepampang sebagai dewa yang kami puja bersanding sejajar dengan Ikahua, batu keramat tempat tradisi penyembelihan perawan dan perjaka sebagai unjuk bukti pemujaan kepada Belaksa Kepampang dan Ikahua yang serupa dengan dewa di kahyangan sana (Bastari, 2019, hal. 21).

Data di atas dengan jelas menggambarkan bahwa penyembelihan perawan dan perjaka ditujukan secara mutlak kepada Belaksa Kepampang dan Ikahua yang diyakini Wangsa Buay Tumi sebagai perwujudan dewata. Adapun waktu penyembelihan itu sendiri dilakukan ketika bulan purnama berwarna merah.

Pokok suci Belaksa Kepampang berpadu kawinkan dengan tradisi Ikahua, sebuah kepercayaan kepada batu atau altar tempat penyembelihan perjaka dan perawan di saat purnama berwarna merah (purnama bakha). Wangsa Buay Tumi berpesta pora pada malam purnama bakha (Bastari, 2019, hal. 29). 
Melalui data di atas dapat diketahui bahwa tradisi penyembelihan itu dilaksanakan ketika bulan purnama berwarna merah atau biasa disebut oleh Wangsa Buay Tumi sebagai bulan purnama bakha. Pada malam penyembelihan itu pula, segenap Wangsa Buay Tumi berpesta pora sebagai wujud syukur juga tanda kebahagiaan karena telah memper-sembahkan seorang perjaka dan perawan kepada Belaksa Kepampang dan Ikahua, sesembahan mereka.

Tradisi penyembelihan perawan dan perjaka pada masa kini sudah tidak ada lagi. tradisi tersebut telah sejak lama mati. Namun yang harus dipahami adalah bahwa melalui tradisi tersebut, kita dapat mengetahui tingginya semangat beragama yang ditunjukkan oleh Wangsa Buay Tumi. Semangat dalam beragama itulah yang tidak boleh mati dalam diri. Agama sebagai pedoman hidup sangat layak ditempatkan pada posisi puncak dalam hidup. Tanpa agama, seseorang tidak akan memiliki pijakan yang kokoh dalam mengarungi kehidupan.

Boleh jadi tradisi tersebut banyak ditentang oleh masyarakat masa kini, namun yang harus diingat, tradisi tersebut telah dianggap luhur oleh Wangsa Buay Tumi sebagai sebuah bangsa. Tradisi tersebut adalah bagian tak terpisahkan dari sebuah kepercayaan dalam beragama. Tradisi tersebut adalah sarana terbaik dalam keyakinan Wangsa Buay Tumi di dalam mendekatkan diri kepada Yang Mahakuasa.

Lantas, bagaimana nasib para perawan dan perjaka yang dikorbankan? Bagaimana pula nasib keluarga yang ditinggalkan? Jawabnya, sebuah tradisi yang telah diyakini bersama akan melahirkan sebuah keralaan penuh terkait dengan konsekuensi yang mungkin timbul dari tradisi yang diyakininya tersebut. Selain itu, seseorang yang dikorbankan untuk sesuatu yang dianggap agung tidak akan mungkin mati dalam keadaan sia-sia. Mereka akan memperoleh balasan kemuliaan dari yang diagungkannya tersebut. Begitu pulalah yang diyakini oleh Wangsa Buay Tumi terkait pengorbanan yang dilakukan.

\section{e. Tradisi Pernikahan Keluarga Kerajaan}

Hikayat Komering Pitu Phuyang juga menggambarkan sebuah tradisi dalam bentuk aturan pernikahan bagi keluarga kerajaan Skala Brakh. Tradisi tersebut tidak ditunjukkan secara langsung, melainkan melalui perlawanan tradisi yang dilakukan oleh salah satu keluarga kerajaan.

Lalu, anak laki-lakiku, Kekuk Sekuik, ynag melawan tradisi moyang kami, menikahi seperudu, perempuan kasta bawah di kerajaanku sehingga hak tahta kerajaanku tercerabut darinya dan kubuang mereka ke muara (Bastari, 2019, hal. 24)

Data di atas secara tidak langsung menggambarkan sebuah tradisi menge-nai larangan menikah bagi keluarga kerajaan dengan seseorang yang berasal dari kasta bawah. Apabila hal tersebut dilanggar, maka akan berdampak besar pada tatanan kehidupan di kerajaan. Sebagaimana yang tergambar pada data di atas, sikap Kekuk Sekuik yang melawan tradisi dengan menikahi perempuan dari kasta bawah menyebabkan tercabutnya hak kerajaan yang dimiliki Ratu Sekerumong atas anaknya, Kekuk Sekuik. Artinya, Ratu Sekerumong sudah tidak memiliki hak untuk menurunkan kepemimpinan atas kerajaan Skala Brakh kepada anaknya karena telah melanggar tradisi turun-temurun dari nenek moyang. 


\section{f. Tradisi Bertapa di Puncak Gunung}

Tradisi luhur lainnya yang terkandung di dalam hikayat Komering Pitu Phuyang adalah bertapa di puncak gunung. Tradisi ini merupakan salah satu cara yang dilakukan untuk mendekatkan diri kepada para dewata. Tradisi ini biasanya dilakukan oleh para petinggi kerajaan dengan berbagai maksud dan tujuan, mulai dari berdoa kepada dewa agar diberikan solusi atas permasalahan yang terjadi hingga wujud syukur atas karunia dan keselamatan yang diberikan dewa.

Pusat daerah baru yang dimaksudkan oleh Ratu Sekerumong adalah daerah yang seperti dibisikkan oleh para dewata ketika Ratu sedang bersemedi di atas puncak Gunung Pesagi (Bastari, 2019, hal. 47).

Data di atas secara tidak langsung menunjukkan kegiataan bertapa atau bersemedi yang dilakukan Ratu Sekerumong hingga beliau mendapatkan bisikan dari para dewata mengenai daerah baru yang harus ditemukan oleh ketujuh paksi sebagai tempat hidup yang baru bagi Wangsa Buay Tumi. Ratu Sekerumong sering melakukan pertapaan guna mencari ketenangan, solusi atas segala permasalahan, sekaligus cara yang dilakukan untuk mendekatkan diri kepada Yang Kuasa.

Tradisi bertapa di puncak gunung juga ditunjukkan oleh para paksi. Hal ini dapat diketahui melalui data berikut.

"Kami bertiga akan bersemedi untuk sanjungkan doa kepada para dewa, atas bantuan mereka melalui dirimu" (Bastari, 2019, hal. 120).

Dengan satu hempasan sayap, Kapodang terbang menuju Gunung Pesagi, tempat Wangsa Buay Tumi dan Ratu Sekerumong. Sedangkan ketiga paksi mengambil posisi masing-masing untuk bersemedi di atas gunung tersebut (Bastari, 2019, hal. 121).

Data-data di atas menggambarkan dengan jelas bahwa bertapa di atas puncak gunung merupakan cara yang digunakan Wangsa Buay Tumi, khususnya petinggi kerajaan Skala Brakh dalam mendekatkan diri kepada para dewata. Hal itu menunjukkan sikap religiositas yang tinggi dimiliki oleh Wangsa Buay Tumi. Hal ini dikarenakan untuk menuju puncak gunung saja dibutuhkan perjuangan yang tidak kecil dan ini sering mereka lakukan demi menjaga kedekatan dengan para dewata.

\section{g. Sistem Kepercayaan yang Dianut}

Wangsa Buay Tumi yang dipimpin oleh Dapunta Dalom Ratu Sekerumong memegang erat kepercayaan terhadap Belaksa Kepampang dan Ikahua. Hal ini dapat diketahui melalui data berikut.

La Laula sebagai daulat raja pertama, dibangun dengan peradaban Hindu dengan kepercayaan kepada dewa-dewa, dengan penyembahan utama kepada Belaksa Kepampang (pohon nangka bercabang) dan Ikahua sebagai altar pemujaan (Bastari, 2019, hal. 28). 
Data di atas menggambarkan bahwa penyembahan terhadap belaksa kepampang dan Ikahua telah ada semenjak La Laula, raja pertama dari kerajaan Skala Brakh berkuasa. La Laula sendiri merupakan kakek buyut dari Ratu Sekerumong, raja terbesar sekaligus terakhir dari kerjaan Skala Brakh. Data di atas juga menggam-barkan bahwa sejatinya Wangsa Buay Tumi beragama Hindu, namun penyembahan utamanya tidak ditujukan kepada dewa-dewa, melainkan kepada Belaksa Kepampang dan Ikahua. Bangsa Buay Tumi percaya bahwa keduanya hidup, bernyawa, dan memiliki kemampuan sebagaimana kemampuan para dewata.

\section{h. Sikap Hidup Wangsa Buay Tumi}

Wangsa Buay Tumi merupakan masyarakat yang menjunjung tinggi nilainilai kebenaran. Mereka meyakini bahwa nilai-nilai kebenaran akan membawa pada kebahagiaan. Melalui Hikayat Komering Pitu Phuyang, dapat diketahui beberapa prinsip hidup yang dianut oleh Wangsa Buay Tumi.

\section{(1) Cinta Damai}

Bangsa Buay Tumi merupakan wangsa yang cinta damai. Mereka tidak pernah mencari permasalahan dengan bangsa lain. Sebaliknya, mereka adalah wangsa yang selalu menerima dengan tangan terbuka setiap orang yang datang ke daerahnya. Mengenai prinsip hidup tersebut dapat diketahui melalui data berikut.

"Sebelum ber-muhibah ke muara, kalian bertujuh harus tahu tentang Sasindai itu. Taklukkan mereka dengan damai." Demikian pesan Ratu kepada tujuh paksi tersebut. Mereka mengangguk tanda paham atas titah sang ratu (Bastari, 2019, hal. 47).

Data di atas dengan tegas menggambarkan sikap hidup Wangsa Buay Tumi yang cinta damai. Jangankan kepada manusia, bahkan kepada hantu Sasindai yang sejatinya kayak dibantai tanpa belas kasihan pun masih diberikan batasan. Ratu Sekerumong selaku pimpinan kerajaan Skala Brakh memerintahkan ketujuh paksi agar bisa mengalahkan hantu Sasindai dengan penuh damai. Ratu Sekerumong meyakini bahwa keda-maian akan selalu bermuara pada kebahagiaan yang sejati.

\section{(2) Religius}

Religius merupakan sebuah nilai hidup manusia yang dimaknai sebagai rasa kebersamaan yang menyatu pada sesuatu yang tidak dapat terlihat, namun diyakini dengan sepenuh hati serta dilakukan secara konsiten dalam kehidupannya seharihari. Sikap religius dalam hikayat Komering dimunculkan pengarang melalui beberapa tokoh, khususnya para paksi yang berjumlah tujuh.

Tabuh canang bertalu-talu. Rapal doa dipanjatkan oleh pandita negeri Liman Meraksa, agar perjalanan para paksi ke muara selamat, serta dapat segera menemukan tanah bisikan para dewa kahyangan (Bastari, 2019, hal. 50).

Data di atas menggambarkan prosesi doa bersama yang dipimpin pandita negeri Liman Meraksa. Doa tersebut dilaksanakan dalam rangka melepas kepergian para paksi dan memulai perjalanannya mencari tanah harapan. 
Perjalanan tersebut harus mereka tempuh demi Wangsa Buay Tumi agar tetap berjaya. Doa merupakan perwujudan sikap religius yang nyata. Berdoa menunjukkan bahwa diri tiada punya daya dan upaya untuk mencari selamat. Semua harus dikembalikan kepada Yang Mahakuasa, dzat yang di tangannya segala ciptaan tergenggam sempurna.

Para paksi memanjatkan syukur kepada dewata atas keselamatan yang mereka dapatkan dari rintangan dalam perjalanan muhibah ke tanah harapan (Bastari, 2019, hal. 58).

Adapun data di atas menggam-barkan sikap religiositas dari para paksi yang tujuh. Mereka memanjatkan syukur kepada dewata atas keselamatan yang telah mereka dapatkan. Mereka sadar bahwa tanpa bantuan dewata, mustahil mereka dapat selamat dari segala marabahaya yang menghadang.

\section{(3) Kesediaan Bertanggung Jawab}

Bertanggung jawab merupakan kesediaan menanggung tugas yang telah diamanahkan dan berusaha menyelesaikannya dengan sebaik mungkin (Suseno, 2005; Hartono, 2014). Wangsa Buay Tumi dalam hikayat digambarkan sebagai wangsa yang penuh tanggung jawab. Hal tersebut dibuktikan melalui sikap petinggi kerajaan hingga rakyatnya. Semuanya bergerak membangun peradaban baru di tempat yang baru. Setiap orang melaksanakan tanggung jawab sesuai prosinya masing-masing.

Dapunta Ratu Sekerumong selaku Ratu bagi kerajaan Skala Brakh memikul tanggung jawab terbesar. Beliau memerintahkan ketujuh paksi untuk ber-muhibah, melakukan perjalanan mencari dan menemukan tanah harapan. Beliau sendiri tetap di kerajaannya, dan mati dalam keadaan mempertahankan kehormatan kerajaan Skala Brakh.

Keempat manusia dari utara yang kemudian merebut papadun, singgasana lambang kekuasaan negeri Skala Brakh, aku Dapunta Beliau Ratu Sekerumong, membawa mati kepercayaan akan-ku, Kajong Dalom, dan Kajong Buyutku, tak akan tergantikan oleh apapun. Biarlah anak cucuku nanti mengingatku sebagai Ratu Sekerumong yang mati dengan mempertahankan kepercayaan para Phuyang kerajaan Skala Brakh, kerajaan Wangsa Buay Tumi (Bastari, 2019, hal. 25).

Melalui kutipan di atas, jelas terlihat betapa besarnya rasa tanggung jawab yang dimiliki oleh Dapunta Beliau Ratu Sekerumong. Beliau teguh dalam pendiriannya, dengan tetap mempertahankan kepercayaannya dan mati dengan mempertahankan kepercayaan sekaligus kehormataan kerajaan Skala Brakh. Kerajaan yang telah dipimpinnya bertahun-tahun itu harus takluk oleh kekuatan Wangsa Buay Umpu dari utara. Dapunta Beliau Ratu Sekerumong mati dalam puncak kehormatan tertinggi karena mempertahankan kehormatan leluhur. Ia juga adalah seorang ratu yang tetap mampu menjaga Wangsa Buay Tumi hingga kematian datang menjemputnya.

Para paksi juga telah melaksanakan tanggung jawabnya sebagaimana yang telah diamanahkan Ratu Sekerumong. Mereka bertujuh dengan penuh keberanian 
menempuh medan yang sulit, segala rintangan menghadang selalu dihadapinya dengan penuh keyakinan. Mereka tidak pernah memutuskan untuk mundur seberat apapun rintangan yang menghadang. Mereka percaya bahwa Dapunta Beliau Ratu Sekerumong telah meletakkan keberlangsungan hidup Wangsa Buay Tumi kepada mereka.

Demikian pula Wangsa Buay Tumi secara keseluruhan, mereka dengan penuh kesadaran dan kepatuhan ber-muhibah ke tempat-tempat yang telah dibuka oleh ketujuh paksi. Tidak ada seorang pun dari mereka yang memberontak atau pun membantah titah pimpinan. Hal ini menunjukkan bahwa mereka telah melaksanakan tanggung jawab sebagai rakyat dengan baik pula.

\section{(4) Pekerja Keras}

Sikap hidup Wangsa Buay Tumi yang berikutnya adalah pekerja keras. Mereka menjadi wangsa yang besar karena usaha dan ketekunan, bukan warisan nenek moyang. Kalaupun toh memang ada warisan dari nenek moyang, namun kebesaran yang diwariskan tersebut akan hilang dalam sekejap mata jika generasi selanjutnya hanya duduk berpangku tangan, menunggu takdir datang.

Sikap hidup pekerja keras Wangsa Buay Tumi digambarkan pengarang melalui ketujuh paksi yang ber-muhibah mencari tanah harapan. Ketujuh paksi dengan tekat yang kuat pergi mencari tanah harapan yang dijanjikan dewata. Mereka dengan penuh keteguhan dan keberanian mengarungi sungai, hutan, dan segala halang rintang yang datang silih berganti. Seberat apapun halangan menghadang, mereka selalu meng-hadapinya bersama-sama. Hingga satu demi satu tanah harapan yang dijanjikan dapat ditemukan. Berkat kerja keras merekalah Wangsa Buay Tumi dapat melebarkan sayapnya, menciptakan kebudayaan baru yang penuh peradaban.

"Cepat kau hantamkan peliung itu ke perut ikan naga sebelum matahari habis dimakan olehnya!"

Suara itu berkali-kali terdengar oleh Paksi Ratu Penghulu.Ikan naga raksasa tersebut hampir memakan matahari setengahnya. Sadar akan hal tersebut, Paksi Ratu Penghulu secepatnya menghantamkan peliung sakti milik Minak Adipati, tepat di perut ikan naga raksasa pemakan matahari. Berkali-kali sehingga sang ikan naga raksasa memuntahkan matahari yang sedang dimakannya. Perlahan tapi pasti, matahari kembali menyinari semesta. Ikan naga raksasa berwarna tembaga tersebut kesakitan dan mulai menyerang Paksi Ratu Penghulu. Belum sempat ikan naga raksasa itu menyerang, secepat kilat Paksi Ratu Penghulu mengarahkan hantaman peliung ke kepala ikan naga raksasa tersebut sehingga pecah berhamburan seketika. Tubuh ikan berwarna tembaga tersebut diselimuti oleh merah darahnya sendiri (Bastari, 2019, hal. 88-89).

Kutipan di atas menggambarkan salah satu wujud kerja keras dari ketujuh paksi dalam menghadapi segala marabahaya yang dating silih berganti di sepanjang perjalanan mencari tanah harapan. Suatu hari, ketika ketujuh paksi dihadang oleh ikan naga raksasa di tengah perjalanan, ketujuh paksi dengan dipimpin oleh Paksi Ratu Penghulu melawan ikan naga raksasa tersebut dengan penuh keberanian serta kehati-hatian. Mereka selalu bekerja sama, saling membantu, dan bahu membahu 
sehingga segala kesulitan yang datang dapat dihadapi dan diselesaikan dengan baik.

\section{i. Sistem Bertempat Tinggal}

Wangsa Buay Tumi yang dipimpin oleh tujuh paksi memiliki kekhasan selalu mendiami atau tinggal di tempat yang dekat dengan sungai. Hal ini bisa dilihat melalui data berikut.

Merekalah cikal bakal suku bangsa Komering yang pertama kali mendiami lembah sungai Komering. Mereka pula yang pertama kali mengadakan muhibah Wangsa Buay Tumi ke daerah muara (Bastari, 2019, hal. 58).

Data di atas menggambarkan bahwa Wangsa Buay Tumi yang merupakan cikal bakal suku bangsa Komering menjadikan lembah sungai Komering sebagai tempat tinggalnya. Mereka meyakini bahwa daerah di sekitaran sungai memiliki tingkat kesuburan lebih tinggi dari daerah mana pun. Itulah salah satu alasan mereka tinggal di daerah-daerah yang dekat dengan sungai. Kenyataan tersebut juga menunjukkan bahwa Wangsa Buay Tumi sebagai cikal bakal suku Komering merupakan sebuah wangsa yang memiliki pemikiran luas dan maju.

\section{PENUTUP}

Berdasarkan penelitian yang telah dilakukan, dapat disimpulkan bahwa Hikayat Komering Pitu Phuyang mengandung kearifan lokal yang sangat beragam. Kearifan lokal yang dimaksud meliputi: (1) keyakinan Wangsa Buay Tumi terhadap tambo sebagai salah satu sarana informasi yang diyakini kebenarannya, (2) sistem kepercayaan terhadap Belaksa Kepampang dan Ikahua sebagai perwujudan dewata, (3) tradisi pemberian adok sebagai wujud penghargaan, (4) sistem pemerintahan berwujud kerajaan, (5) tradisi penyembelihan perawan dan perjaka sebagai bukti pemujaan terhadap dewata, (6) tradisi kasta dalam pernikahan keluarga kerajaan sebagai simbol kehormatan, (7) tradisi bertapa di puncak gunung sebagai sarana pendekatan diri kepada Yang Kuasa. (8) masyarakat yang memiliki prinsip hidup religius, penuh tanggung jawab, dan pekerja keras, serta (9) sistem bertempat tinggal yang mencerminkan keluasan cara pikir masyarakatnya. Wangsa Buay Tumi sendiri dipercaya merupakan cikal bakal suku Komering yang pertama kali mendiami lembah sungai Komering.

\section{DAFTAR PUSTAKA}

Alwi, H. (2005). Kamus Besar Bahasa Indonesia: Edisi Ketiga. Jakarta: Balai Pustaka.

Bastari, H. (2019). Negeri Para Phuyang: Hikayat Komering Pitu Phuyang. Kebumen: Intishar Publishing.

Fachrudin. (2009). Menggali kearifan lokal daerah Lampung untuk Penanggulangan

Problema Sosial. Bandar Lampung: Dinas Sosial Provinsi Lampung.

Jabrohim. (2015). Teori Penelitian Sastra.Yogyakarta:Pustaka Pelajar.

Hartono. (2014). Pendidikan Karakter dalam Kurikulum 2013. Jnana Budaya, 19(2), 259-268.

https://jurnalbpnbbali.kemdikbud.go.id/jurnal/index.php/Jnana/article/vie 
$\mathrm{w} / 21$

Kasmi, H. (2019). Nilai-Nilai Kearifan Lokal dalam Novel Tempat Paling Sunyi Karya Arafat Nur. Jurnal Metamorfosa, 7(2), 161-169. https://ejournal.bbg.ac.id/metamorfosa/article/view/260

Koentjaraningrat. (1987). Manusia dan Kebudayaan di Indonesia. Yogyakarta: Djambatan.

Misyuraidah, M. (2017). Gelar Adat dalam Upacara Perkawinan Adat Masyarakat Komering di Sukarami Ogan Komering Ilir Sumatera Selatan. Intizar, 23(2), 241-260. https://doi.org/10.19109/intizar.v23i2.2239

Murmahyati. (2011). Kearifan Lokal dalam Puisi Toraja. Sawerigading, 17(2), 269278. https://doi.org/10.26499/sawer.v18i2.356

Purna, I. M. (2016). Local Wisdom of Mbawa Village Society in Building Religious Tolerance. Jurnal Pendidikan Dan Kebudayaan, 1, 265.

Rafiek, M. (2012). Kearifan Lokal dalam Hikayar Raja Banjar. International Journal of the Malay World and Civilisation, 30(1), 67-104.

Ratna, N. K. (2015). Teori, Metode, dan Teknik Penelitian Sastra. Yogyakarta: Pustaka Pelajar.

Rohmadi, M., \& Yakub N. (2017). Dasar-Dasar Penelitian Bahasa, Sastra, dan Pengajaran. Surakarta: Pustaka Briliant.

Salbiah, S., \& Fitriani, H. (2021). Analisis Penokohan Dalam Hikayat Komering Phitu Phuyang: Negeri Para Phuyang Karya Himawan Bastari. Seulas Pinang: Jurnal Pendidikan Bahasa Dan Sastra, 2(1), 32-42. https://doi.org/10.30599/spbs.v2i1.820

Sartini. (2004). Menggali Kearifan Lokal Nusantara. Jurnal Filsafat, 37(2), 111-120. https://jurnal.ugm.ac.id/wisdom/article/view/33910/20262

Suharso., \& Retnoningsih, A. (2020). Kamus Besar Bahasa Indonesia: Edisi Lux. Semarang: Widya Karya.

Supratman. (1996). Ikhtisar Sastra Indonesia. Bandung: Pustaka Setia.

Suseno, F. M. (2005). Etika Dasar: Masalah-Masalah Pokok Filsafat Moral. Jakarta: Pustaka Filsafat.

Yetti, E. (2019). Kearifan Lokal dalam Cerita Rakyat Nusantara: Upaya Melestarikan Budaya Bangsa. Mabasan, 5(2), 13-24. https://doi.org/10.26499/mab.v5i2.207 